\title{
Economic Liberalisation and Manufacturing Productivity in Nepal
}

\author{
Kishor Sharma
}

I

$\mathrm{N}$ recent years, the debate about trade orientation and productivity growth has produced a number of studies of individual developing countries and of comparisons between them. These studies have confirmed that outward-oriented economies grow faster than inward-oriented economies because they utilise their resources more efficiently. Such studies have concentrated on middle- and highincome rather than low-income developing countries. But the experience of the former cannot be generalised to the latter, given that the level of human capital, the state of physical infrastructure, and the level of $R \& D$ are substantially lower in lowincome developing countries. The analysis of the experience of a wide range of economies with different backgrounds could therefore provide fresh insights into the impact of economic reform in different environments (Papageorgiou et al., 1991).

Nepal is a low-income, land-locked developing country that adopted an outward-oriented strategy from the mid-1980s. Before then, it was widely believed in Nepal that policies of import substitution would encourage the growth of a wide range of industries and also generate a sufficient level of government revenue from tariffs and quotas. As well, the country's land-locked position and open border with India forced it to adopt a tariff and incentive regime similar to India's: a lower tariff than India's would have promoted smuggling, thus draining Nepal's foreign exchange reserves, while more generous export incentives would have caused the reexport of Indian goods. ${ }^{1}$ But the resulting inefficiencies prompted the Nepalese government to substantially liberalise the economy from 1986/87. This article assesses the impact of this policy shift on the growth of manufacturing productivity.

\section{Historical Background}

Nepal virtually had a free trade policy until 1955. With the advent of the first economic plan in 1956, import restrictions were introduced to promote importsubstituting industries (ISIs). Domestic and foreign investment was regulated by means of a rigorous licensing system, and industrialisation was supported by subsidised credit. Under legislation introduced in 1961, ISIs were protected from exter-

\footnotetext{
${ }^{1}$ See Blejer and Szapary (1991) for further discussion of this issue.
}

Kishor Sharma is Lecturer in Economics at Charles Sturt University (Wagga Wagga). 
nal competition for a minimum of five years; but in many cases protection was extended for a longer period. By the late 1960s, the domestic market had been shielded from external competition. Many large-scale industries were established in the public sector, on the assumption that the private sector lacked resources and management skills. The number of manufacturing public enterprises rose from two in 1962 to 23 in 1985 . They were given privileged access to imported inputs and technology, and received a high level of protection; but their returns were disappointing.

Exports, meanwhile, were regulated through an export licence system and an export tax. Rice and oil producers were required to sell a certain percentage of their output to the Nepal Food Corporation at below-market prices. By the early 1970s, exports of rice, the major export item in the 1970s, were channelled through the Paddy and Rice Exporting Corporation (PREC), whose prices, being much lower than the international market prices, resulted in a sevenfold fall in the value of rice production between 1972/73 and 1986/87. Exports declined as well, and PREC was dissolved in the mid-1980s.

\section{Table 1}

\section{Nepal: macroeconomic indicators (annual percentage of real GDP, unless otherwise stated)}

\begin{tabular}{lccc}
\hline \multicolumn{1}{c}{ Indicators } & $1974 / 75$ & $\begin{array}{c}1976 / 77- \\
1986 / 87\end{array}$ & $\begin{array}{c}1987 / 88- \\
1993 / 94\end{array}$ \\
\hline Real GDP growth & & 3.0 & 4.1 \\
Exports & na & 5.1 & 7.0 \\
Imports & 5.4 & 17.4 & 22.6 \\
Trade deficit & 10.9 & 12.3 & 14.8 \\
Current account deficit & 5.6 & 3.5 & 7.2 \\
Budget deficit & 0.7 & 6.9 & 7.2 \\
International reserves & 1.3 & 3.8 & 6.5 \\
(months of imports) & 7 & & \\
\hline
\end{tabular}

Notes: GDP deflator is used to obtain the real data. Real GDP growth rate is average annual.

Sources: Ministry of Finance, Economic Survey (various issues) and Nepal Rastra Bank, Quarterly Economic Bulletin (various issues).

The licensing of imports of intermediate inputs discouraged production of manufactured goods. Obtaining an import licence could take several weeks. Manufacturers tended to build up inventories of intermediate inputs for future use or even to sell the import licences to merchants. Even though ISIs and exportoriented industries (EOIs) were accorded equal priority in development plans, in practice ISIs received more protection because of the widespread view among bureaucrats that they could eventually lead to export development. The consequent 
deterioration in real export earnings led to a tightening of restrictions on imports of intermediate inputs and consumer goods, resulting in poor capacity utilisation in private sector industries. By 1985 , about 95 per cent of Nepal's imports were subject to licensing, foreign-exchange controls or tariffs; and the dispersion in statutory tariff levels was huge (IMF, 1992). Widespread under-invoicing of imports promoted a black market in foreign currencies.

By the mid-1980s, the net effects of these restrictive policies were visible (see Table 1). Per capita GDP was growing slowly due partly to sluggish growth in output and partly to rapid population growth, which reached 2.6 per cent a year in the late 1970s and early 1980s. It became clear to policy-makers and planners that sustainable development could not be achieved without substantial policy changes.

\section{Economic Liberalisation}

Trade policy, the foreign exchange market, investment policy (including foreign investment), and the operation of public sector enterprises were all reformed from the mid-1980s. The process of liberalisation in trade policy began from the mid1980s by lowering tariffs, expanding the import-licence auction system, and increasing the number of items under the open general licence system. The number of commodities requiring import licences was reduced from 143 to twelve by mid1992; licensing was finally ended in 1993/94. Since February 1993, the Nepalese currency has been fully convertible for all current-account transactions at marketdetermined exchange rates.

Attempts have been made to reduce the dispersion of tariff rates. Until the mid-1980s, there were more than 300 import duty rates, ranging from 1 per cent to 450 per cent. By the early 1990 s the range had been reduced to between 5 per cent and 110 per cent. The 17 sales tax rates were reduced to four by 1991/92 and to two by 1993/94. Currently, sales tax rates are linked to import duty rates in the interests of making the trade regime more transparent. Similarly, the number of excisable products has been reduced from 33 to eleven, and the ranges of excise duties have been rationalised.

Additional duties on the imports from countries other than India were also cut to a range of 15-50 per cent by the early 1990s and to 3-12 per cent in March 1993. Additional duties on goods imported from member countries of the South Asian Association for Regional Cooperation are exempted at the rate of 10 per cent, while the difference between import duties on industrialists and those on traders has been abolished. A substantial fall in tariffs, sales tax and excise duties has resulted in a decline in the trade-weighted nominal rate of protection from about 80 per cent in the mid-1980s to about 31 per cent in 1993/94. (see Figure 1).

On the investment front, a liberal industrial policy was declared in 1987. This policy was designed to remove distortions by simplifying the registration procedures and extending incentives such as the provision of pre-export loans, duty drawback (import duty repaid to exporters) and bonded warehouse facilities to EOIs. Industrial registration and licensing procedures have been extensively amended. No licence is required for establishing, expanding or modernising industries, or, since 
early 1996, for foreign investments of less than US $\$ 300,000$, apart from those concerned with defence, public health and the environment.

Figure 1

\section{Trade-weighted nominal rate of protection (\%), 1976/77-1993/94}

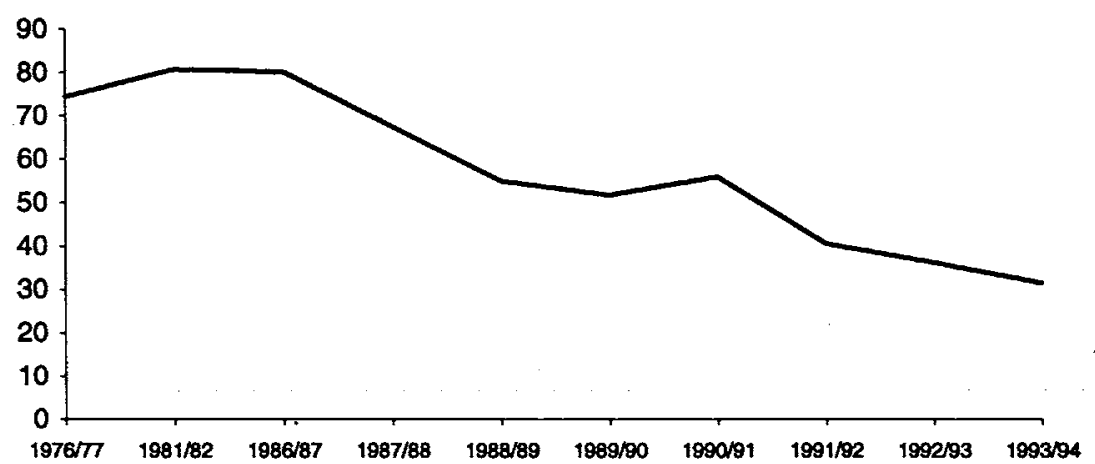

Notes: Imports from India are subject to lower protection than other imports, since they are subject to the basic tariff only, whereas imports from the rest of the world are taxed using the basic plus additional tariff. A single trade-weighted nominal rate of protection is obtained from the trade shares of India and the rest of the world.

Sources: Department of Customs and Department of Sales Tax and Excise Duty.

Finally, government interventions in production and trading activities have been gradually reduced by privatising state-owned enterprises and liquidating financially unviable enterprises. By 1993, two public corporations had been liquidated and eight enterprises privatised. The government is currently privatising cigarette and sugar factories operating in the public sector.

\section{Liberalisation and Total Factor Productivity Growth}

Total factor productivity (TFP) growth can be estimated in either value-added terms or output terms, which give similar results (Krueger \& Tuncer, 1982). However, the latter approach, in which intermediate inputs are treated as a separate factor of production, is adopted here. Like many developing countries, Nepal relies extensively on imported intermediate inputs, whose availability substantially influences capacity utilisation and productivity growth. The pre-reform licensing system often prevented firms from importing sufficient inputs, leading to a lower level of output and poor capacity utilisation. Estimates of TFP growth based on gross output should capture the effect of changes in the availability of imported inputs on output and TFP growth. 
TFP growth is defined as output growth minus the weighted average input growth where the weights are the value shares of each input. To estimate TFP growth, initial and terminal year observations were taken from each of the prereform and post-reform periods. The average of the factor shares in the first and the last year of each period was used to obtain the weighted average growth in factor inputs. This choice of measurement was guided mainly by the nature of data: for the pre-reform period, manufacturing data a e available every five years, while for the post-reform period these data are available annually except for 1992/93.

To test the robustness of our results, TFP growth was estimated for both subperiods, based on the growth rates obtained from two alternative techniques: (i) a regression, which uses all available observations, and (ii) the average of the first two years' and of the last two years' data. Applying the sub-periods' average factor shares, TFP growth was estimated from the growth rates obtained through method (i). To estimate TFP growth from the growth rates obtained through method (ii), the average of the first two years' and of the last two years' factor shares was used. The TFP growth estimates, based on the growth rates obtained from the initial and terminal year observations, do not significantly deviate from those obtained from methods (i) and (ii), indicating that the results are robust.

\section{Table 2}

\section{Average annual percentage growth in output, weighted factor inputs and manufacturing TFP, before and after liberalisation}

\begin{tabular}{lcccccc}
\hline & \multicolumn{3}{c}{$\begin{array}{c}\text { Pre-liberalisation } \\
(1972 / 73-1986 / 87)\end{array}$} & \multicolumn{3}{c}{$\begin{array}{c}\text { Post-liberalisation } \\
(1987 / 88-1993 / 94)\end{array}$} \\
\hline & EOls & ISIs & Total & EOls & ISIs & Total \\
& & & mfg & & & mfg \\
Output growth & 12.23 & 0.68 & 1.72 & 16.98 & 8.99 & 10.83 \\
Weighted material & 5.07 & -0.012 & 0.05 & 11.86 & 0.92 & 7.09 \\
input* $^{*}$ & $(41.4)$ & $(-1.7)$ & $(2.9)$ & $(69.8)$ & $(10.2)$ & $(65.4)$ \\
Weighted capital $^{\text {input }}$ & 3.60 & 1.29 & 2.17 & 10.95 & 1.06 & 3.53 \\
Weighted labour $^{*}$ & $(29.4)$ & $(189.7)$ & $(126.1)$ & $(64.4)$ & $(11.8)$ & $(32.6)$ \\
input* $^{*}$ & 0.11 & 0.53 & 0.46 & 0.12 & 0.80 & 0.62 \\
TFP growth** & $(0.9)$ & $(77.9)$ & $(26.7)$ & $(0.7)$ & $(8.9)$ & $(5.7)$ \\
& 3.45 & -1.13 & -0.96 & -5.95 & 6.21 & -0.41 \\
& $(28.2)$ & $(-166.2)$ & $(-55.8)$ & $(-35)$ & $(69)$ & $(-3.7)$ \\
\hline
\end{tabular}

Notes: Following Nishimizu and Robinson (1984), industries are classified as either exportoriented industries (EOIs) which export more than 10 per cent of total production, or import-substituting industries (ISIs) which import more than 10 per cent of total domestic supply (imports plus domestic production minus exports).

"The percentage contributions of material inputs, capital, labour and TFP changes to output growth are given in parentheses.

${ }^{\star *}$ The most appropriate price indices for TFP growth analysis are the wholesale price indices (WPI). However, in the absence of WPI and the manufacturing GDP deflator in Nepal, the manufacturing price index $(1992 / 93=100)$ was used, derived from the CPI.

Source: Central Bureau of Statistics (various years). 
A marginal improvement in overall manufacturing productivity following a liberalisation program was detected (see Table 2). TFP improved from minus 0.96 per cent a year in the pre-liberalisation period to minus 0.41 per cent a year in the post-liberalisation period, providing some support for the notion that liberalisation results in productivity growth. ${ }^{2}$ In the pre-liberalisation period, TFP growth was higher in EOIs than in ISIs, seemingly because of the latter's difficulties in obtaining imported inputs and slow growth in domestic demand, leading to excessive unused capacity. This was not a problem for EOIs as they were given import licenses on the ground that they earn foreign exchange. However, in the post-liberalisation period EOIs experienced a fall in productivity growth from 3.45 per cent a year in the earlier period to minus 5.95 per cent a year in the latter period, despite an increase in output. Meanwhile, the productivity performance of ISIs improved from minus 1.13 per cent a year to 6.21 per cent. This could be ascribed to enhanced access to imported inputs, leading to an improvement in capacity utilisation. However, capacity utilisation is still under 60 per cent in manufacturing, mainly because of shortages in electricity supply. ${ }^{3}$

In the post-liberalisation period, productivity improvements have occurred among both EOIs and ISIs. Productivity growth was higher in those ISIs that were least protected in the earlier period, with the exception of distillery and fruit canning. These ISIs comprised vegetable fats, grain mills, bakery products, animal feed, distilled products, bidi, wooden furniture, paper and paper products, printing, drugs and medicine, rubber products, structural clay and non-machinery fabricated metal. However, productivity declined in those ISIs that were highly protected, including the public-sector dominated sugar, dairy, textile, cigarettes and cement industries. Among the public sector dominated ISIs, only the drug and medicine industry, which had been less protected in the pre-reform period, recorded an improvement in productivity in the post-reform period. Furthermore, productivity improved by 7 per cent a year in the privatised footwear industry, which in the earlier period had been a loss-making public enterprise due to overstaffing and lack of competitiveness. This provides some support for the hypothesis that government intervention and high protection could lead to poor TFP growth in developing economies. Kajiwara (1994) finds similar results in the post-reform period for the Philippines.

Among EOIs, only knitting, leather and leather products, and jewellery recorded productivity growth in the post-reform period. The traditional garment and carpet EOIs, which contribute over 80 per cent of manufactured exports, experienced an absolute fall in productivity, apparently because of a shortage of skilled

\footnotetext{
${ }^{2}$ Regime (1994) obtains similar results for the Nepalese manufacturing sector during 1972/73 and 1986/87. He observed the average annual growth of minus 1.68 per cent in TFP during this period. However, his estimates are based on the value-added production function and on the Indian WPI, which may have caused a small upward bias in his estimates.

${ }^{3}$ This is one of the problems currently faced by the manufacturing sector. As liberalisation occurred, demand for electricity increased as new industries came into operation and existing industries improved their capacity utilisation. But electricity supply is lagging behind the rising demand.
} 
labour. This finding is similar to that of Okuda (1994), who finds negative TFP growth in Taiwan's clothing sector following liberalisation. Jute manufacturing also experienced a decline in TFP in the post-reform period.

Table 2 shows that capital input explains a major part of output growth in the overall manufacturing in the earlier period. This reflects the facts that industrialisation was supported in the form of subsidised credit and that import licences were often granted on the basis of installed capacity, creating an incentive for capital accumulation. Thus, capital input explains about 126 per cent of growth. The contribution of intermediate inputs was only about 3 per cent, which seems to be due to excessive restrictions in the imports of inputs. Labour input contributed about 27 per cent to growth, while the contribution of TFP growth was minus 56 per cent. However, this pattern has slightly changed in the latter period. Intermediate inputs explain about 65 per cent of output growth, which appears to reflect increased access to imported inputs following liberalisation. The contributions of capital and labour input to output growth had fallen to about 33 per cent and 6 per cent respectively. The declining share of labour input could be explained by the lower level of human capital and stringent labour legislation which made workplace dismissals more difficult. Furthermore, real wages have increased in recent years: the minimum real wages of unskilled, semi-skilled, skilled and highly skilled labour rose by 93 per cent, 75 per cent, 52 per cent and 29 per cent respectively between 1985 and 1992. Together, these factors seem to have contributed to a fall in the contribution of labour input to output growth. In a labour-abundant country like Nepal, however, it seems unlikely that output growth can be increased in the long term if the contribution of labour remains at around 6 per cent.

\section{Conclusions}

Although Nepal's overall manufacturing TFP declined both before and after the economic reforms of the mid-1980s, the smaller decline in the latter period provides some support for the claim that liberalisation may lead to higher TFP growth. However, its contimued fall suggests that liberalisation is not a sufficient condition for rapid productivity growth in developing economies. Further labour market reforms, improvement in the level of human capital through aggressive training programs, and the provision of reliable infrastructure, such as electricity supply, may improve productivity growth. Nepal's lesson for low-income developing countries seems to be, then, that emphasis should be placed on infrastructure investment as well as on liberalisation. Without basic infrastructure, rapid productivity growth is unlikely to be achieved.

The reforms of the mid-1980s have had little impact on the macroeconomic front. The current account and budget deficits continue to deteriorate, while some improvements have occurred in international reserves and the ratio of exports to GDP. But these improvements have not come about as a result of a substantial improvement in manufacturing productivity growth. The rise in the ratio of exports to GDP ratio appears to be due to lucrative export incentives such as the generalised system of preferences, under which Nepalese exporters are given preferential 


\section{Kishor Sharma}

tariff treatment by developed nations. This is, however, not a reliable incentive and can be suspended at any time by the countries that implement it. Without a substantial improvement in manufacturing productivity, it is unlikely that Nepal would be able to maintain even a 7 per cent ratio of exports to GDP in the long run.

\section{References}

Blejer, M. \& G. Szapary (1991), 'The Gulliver Effect and the Optimal Divergence Approach to Trade Policies: The Case of Nepal', World Development 19: 255-62.

Central Bureau of Statistics, Census and Annual Survey of Manufacturing Establishments (various issues), Kathmandu.

International Monetary Fund (IMF) (1992), Issues and Development in Intemational Trade Policy, Washington DC.

Kajiwara, H., (1994), 'The Effects of Trade and Foreign Investment Liberalisation Policy on Productivity in the Philippines', The Developing Economies 4: 492-508.

Krueger, A. \& B. Tuncer (1982), 'Growth of Factor Productivity in Turkish Manufacturing Industries', Joumal of Development Economics 11: 307-25.

Ministry of Finance, Economic Survey, Kathmandu.

Nepal Rastra Bank, Quarterly Economic Bulletin, Kathmandu.

Nishimizu, M. \& S. Robinson (1984), 'Trade Policies and Productivity Change in Semi-industrialised Countries', Journal of Development Economics 16: 177-210.

Okuda (1994), 'Taiwan's Trade and FDI policies and Their Effect on Productivity Growth', The Dcveloping Economics 4: 424-43.

Papageorgiou, D., M. Michacly \& A. Choksi (eds) (1991), Liberalising Foreign Trade, Vol 7, Basil Blackwell, Oxford.

Regime, G. (1994), Industrial Growth in Nepal: A Sectoral and Regional Analysis, Oxford \& BPI Publishing, New Delhi.

The author would like to thank Sisira Jayasuriya, Premachandra Athukorala, Edward Oczkowski and an anonymous referee for their suggestions and comments on a previous draft. 